\title{
Acute haematological response of a cichlid fish Sarotherodon melanotheron exposed to crude oil
}

\author{
Oriakpono Obemeata ${ }^{1 \star}$, Hart Aduabobo ${ }^{1}$ and Ekanem Wokoma ${ }^{2}$ \\ ${ }^{1}$ Department of Animal and Environmental Biology, Faculty of Science, University of Port Harcourt, P. M. B. 5323 \\ Rivers State, Nigeria. \\ ${ }^{2}$ Department of Crop and Soil Science, Faculty of Agriculture, University of Port Harcourt, P. M. B. 5323 \\ Rivers State, Nigeria.
}

Accepted 5 October, 2012

\begin{abstract}
The acute haematological response of a brackish water cichlid fish Sarotherodon melanotheron exposed to crude oil was evaluated. They were exposed for $96 \mathrm{~h}$ to crude oil concentrations of 0,50 , $125,250,375$, and $500 \mathrm{mg} / \mathrm{L}$ of water obtained from the fish source. Haematological analyses were carried out at 12, 24, 48, 72, and $96 \mathrm{~h}$, respectively. Haematological analysis revealed that the red blood cells (RBC), haemoglobin (Hb), packed cell volume (PCV), thrombocytes, and lymphocytes of the control group were significantly higher $(P \leq 0.05)$ than the crude oil treated groups while the white blood cells (WBC), neutrophils, leucocrit (Lct) and monocytes of the crude oil treated groups were significantly higher than the control group, indicating an immune response to the toxicant. These parameters can be standardised and used as biomarkers in biomonitoring programs.
\end{abstract}

Key words: Haematological response, biomarkers, biomonitoring, Sarotherodon melanotheron, crude oil.

\section{INTRODUCTION}

Haematological indices have been employed in effectively monitoring the responses of organisms to stressors and thus its health status under such adverse conditions. Generally, haematological tests are used to establish normal health status and to diagnose diseases caused by various factors namely heavy metals, environmental stress, parasitic infections, genotoxic effect of pollutants, nutrition, and pollution in human and veterinary science (Fedato et al., 2010). Haematological parameters act as physiological indicators to changing external environments (Caruso et al., 2005) as a result of their relationship with energetic (metabolic levels), respiration (haemoglobin) and defence mechanisms (leukocyte levels). Haematological parameters also provide an integrated measure of the health status of an organism, which over time manifests in changes in weight (Yaji and Auta, 2007).

\footnotetext{
*Corresponding author. E-mail: obytrees@yahoo.com.
}

The assessment of haematological values of fishes are carried out to ascertain the effect of certain chemical pollutants such as insecticides or heavy metals and the variation with age, sex and season (Van Vuren and Hattingh, 1978; Clarke et al., 1979), to determine the effect of disease condition or parasite on the blood values (Barham et al., 1980), and to establish a normal range of blood parameters (Siddiqui and Naseen, 1979). Haematological parameters have been recognised as valuable tools for the monitoring of fish health (Bhaskar and Rao, 1984; Schuett et al., 1997). However, the standardization of haematological parameters is difficult in fish because these parameters can be influenced by deficient diets, diseases and environmental stress situations (Silveira and Rigores, 1989). Nevertheless, the analysis of these parameters may improve the diagnosis of fish health (Blaxhall and Daisley, 1973; Anderson, 1974; Aldrin et al., 1982). This study provides standard haematological values for Sarotherodon melanotheron, a brackish water fish, as a way of establishing fish in healthy, disease and various stress conditions. 


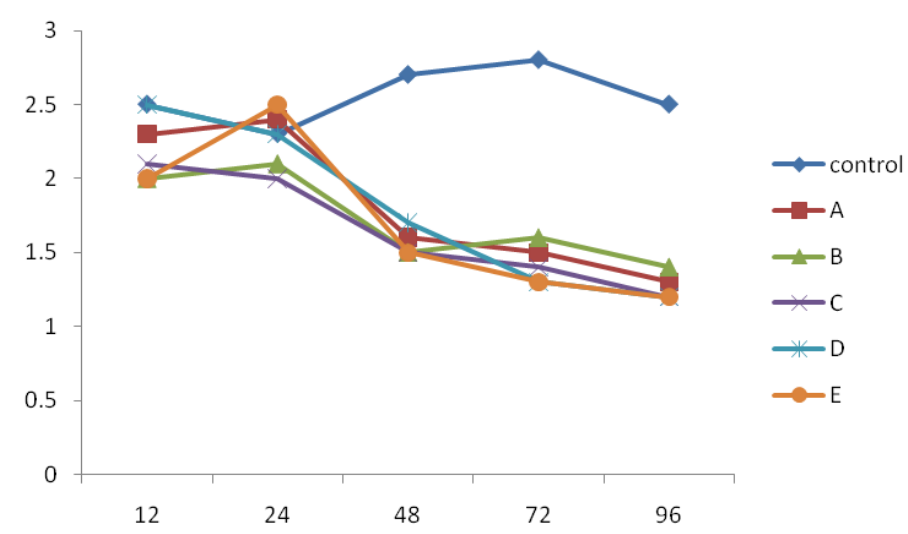

Figure 1. Red Blood Cells - RBC (cells $\times 106 / L$ ) of Sarotherodon melanotheron during the $96-\mathrm{h}$ period.

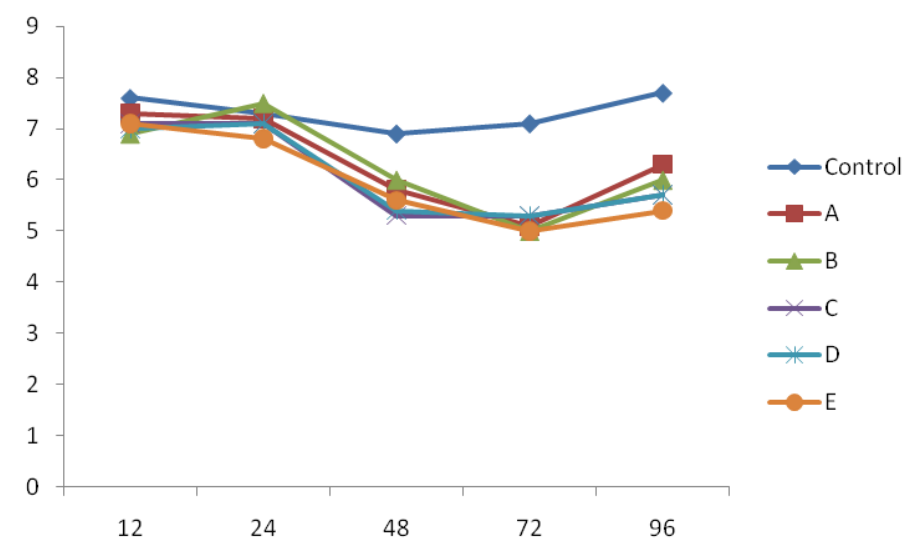

Figure 2. Haemoglobin $-\mathrm{Hb}(\mathrm{g} / \mathrm{L})$ of Sarotherodon melanotheron during the $96-\mathrm{h}$ period.

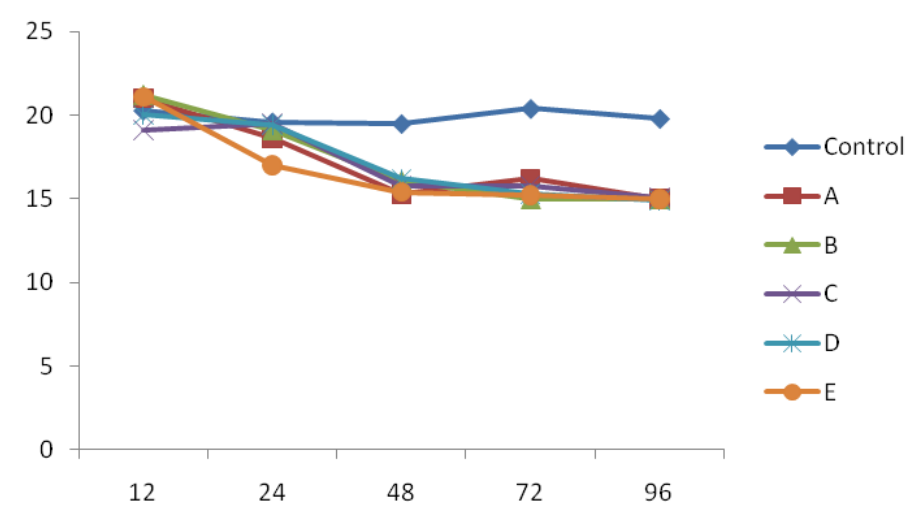

Figure 3. Packed cell volume -PCV (\%) of Sarotherodon melanotheron during the $96-\mathrm{h}$ period.

\section{MATERIALS AND METHODS}

Three hundred and eighty adult male $S$. melanotheron (mean weight $372.56 \pm 9.27 \mathrm{~g}$; mean length $19.32 \pm 4.48 \mathrm{~cm}$ ) were purchased from Brackish Water fish farms, in Buguma and sexed.
They were allowed to acclimatize for seven days, after which they were divided into six vessels in triplicates based on body weight and labelled Control, A, B, C, D, and E, representing concentrations of $0,501,125,250,375$, and $500 \mathrm{mg} / \mathrm{L}$ crude oil exposure. The concentrations were chosen after preliminary studies were conducted with varying concentrations of the test solution. Blood sampling was conducted at the expiration of 12, 24, 48, 72 and $96 \mathrm{~h}$. Blood samples were collected from 90 male $S$. melanotheron with heparinized plastic syringe, fitted with 21 gauge hypodermic needle and preserved in disodium salt of ethylene-diaminetetraacetic acid (EDTA) bottles for analysis. The Blaxhall and Daisley (1973), Brown (1980) and Wedemeyer et al. (1983) haematological methods were adopted for this study. The cyano-haemoglobin method was used to determine haemoglobin $(\mathrm{Hb})$ using diagnostic kits from Sigma diagnostics USA, and packed cell volume (PCV) was determined by the microhaematocrit method. Red blood cell (RBC), leucocrit (LCT) and thrombocyte count were determined with the improved Neubauer haemocytometer according to (Dacie and Lewis, 1991). White blood cells (WBC) was determined with the improved Neubauer counter, while differential counts such as neutrophils, lymphocytes and monocytes were determined on blood film stained with May-Grunwald-Giemsa stain (Mirale, 1982). The completely randomised design was used and analysis of variance was conducted using the SAS software and differences among means were separated.

\section{RESULTS}

Figures 1 to 9 show the results obtained for haematological indices of $S$. melanotheron during the 96-h assay. Statistical analysis conducted with the recorded values of RBC, lymphocytes, thrombocytes, haemoglobin and packed cell volume (PCV) of $S$. melanotheron indicate that the control groups were significantly higher $P<0.05$ than the crude oil treated groups A, B, C, D, and $E$. There were no significant differences between the values of the crude oil treated groups, except for haemoglobin where treatments $A$ and $B$ were significantly higher than treatments $\mathrm{C}, \mathrm{D}$, and $\mathrm{E}$, respectively.

Furthermore, the white blood cells (WBC), leucocrit, neutrophils and monocytes of $S$. melanotheron revealed that the crude oil treated groups were significantly higher $P<0.05$ than the control. The crude oil treated groups showed an increase in WBC, leucocrit, neutrophils and monocytes. However, there were no significant differences between the crude oil treated groups except for the monocytes that had significant differences as treatments $A, C, D$ and $E$ were significantly higher than treatment $B$.

\section{DISCUSSION}

During this study, water quality parameters were maintained within recommended limits. The haematological response of $S$. melanotheron following exposure to different crude oil concentrations revealed a crisis situation indicating they can serve as biomarkers in fish under stress, or when faced with the challenge of a pollutant. 


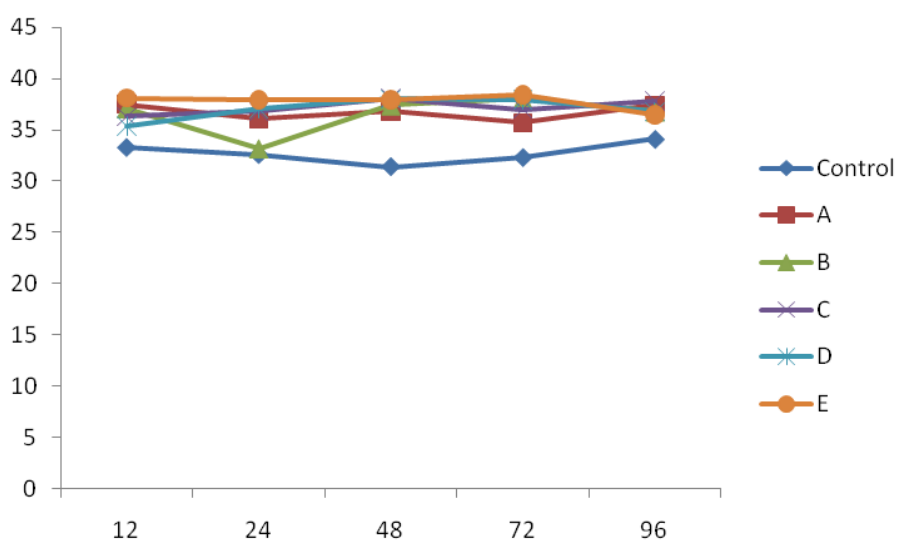

Figure 4. White blood cells -WBC (cells $\times 109 /$ L) of Sarotherodon melanotheron during the 96-h period.

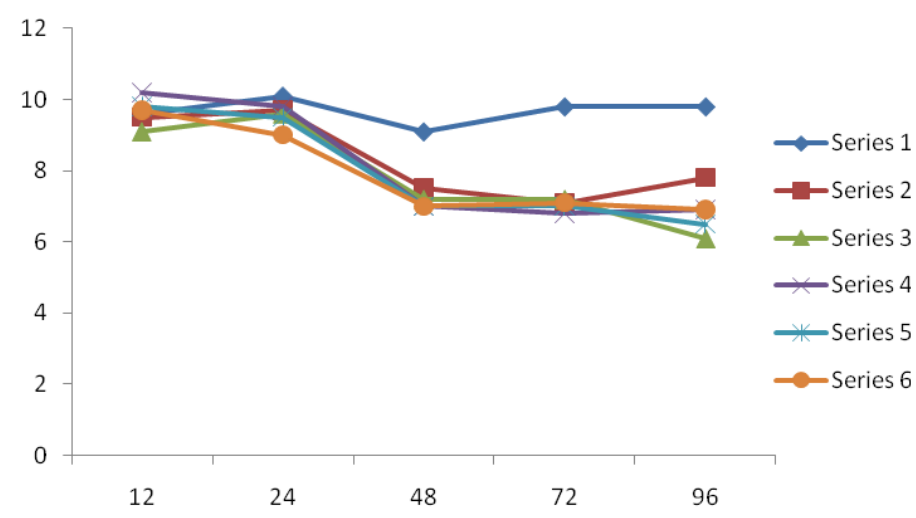

Figure 5. Leucocrit (cells $\times 1012 / \mathrm{L}$ ) of Sarotherodon melanotheron during the $96-\mathrm{h}$ period.

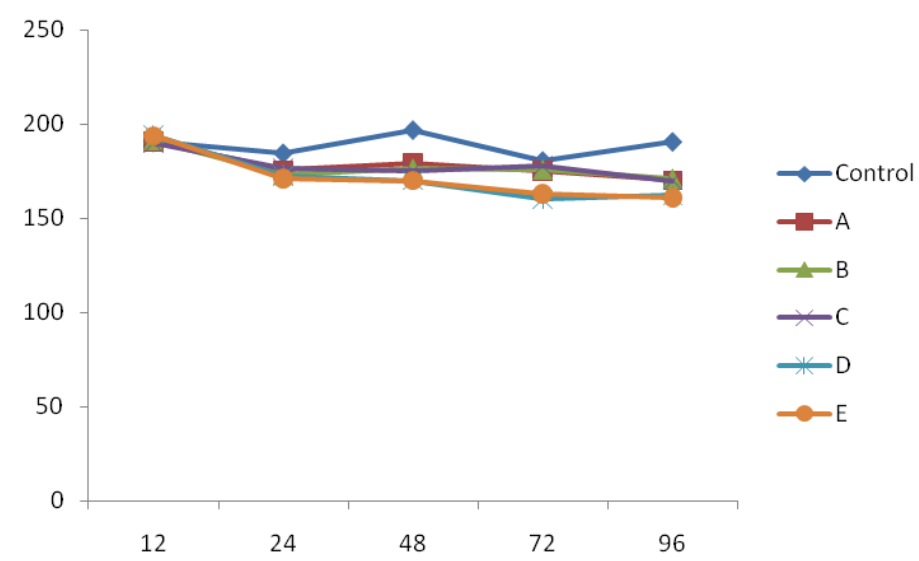

Figure 6. Thrombocytes (\%) of Sarotherodon melanotheron during the $96-h$ period.

The variations found in haematological indices when exposed to crude oil are a defensive mechanism against crude oil toxicity through stimulation of erythropoiesis,

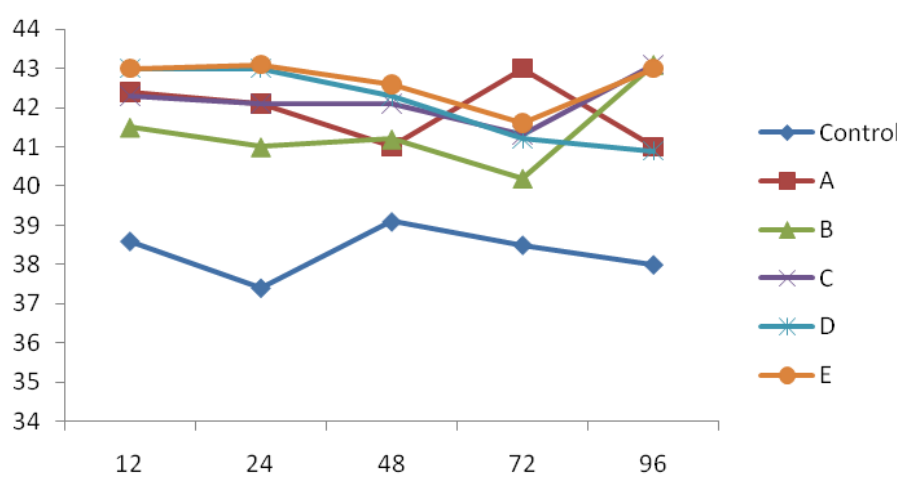

Figure 7. Neutrophils (\%) of Sarotherodon melanotheron during the 96-h period.

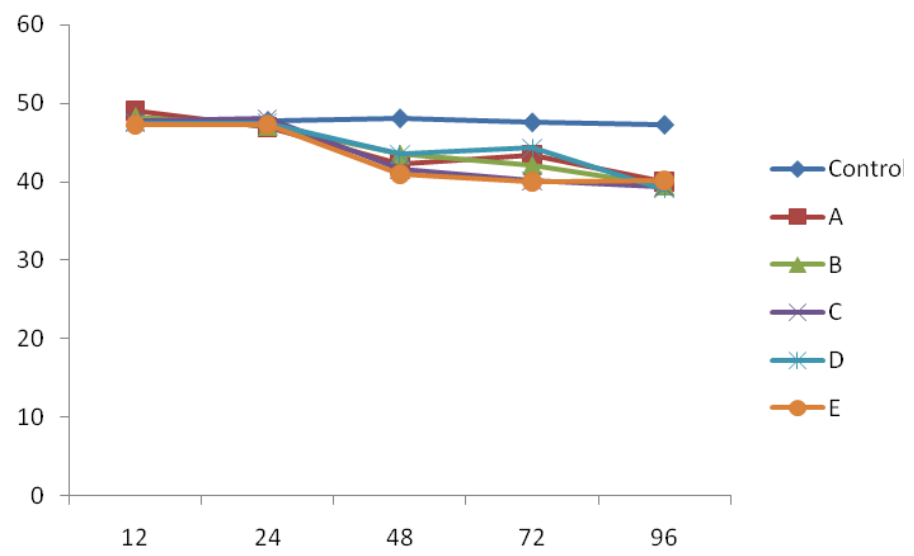

Figure 8. Lymphocytes (\%) of Sarotherodon melanotheron during the $96-h$ period.

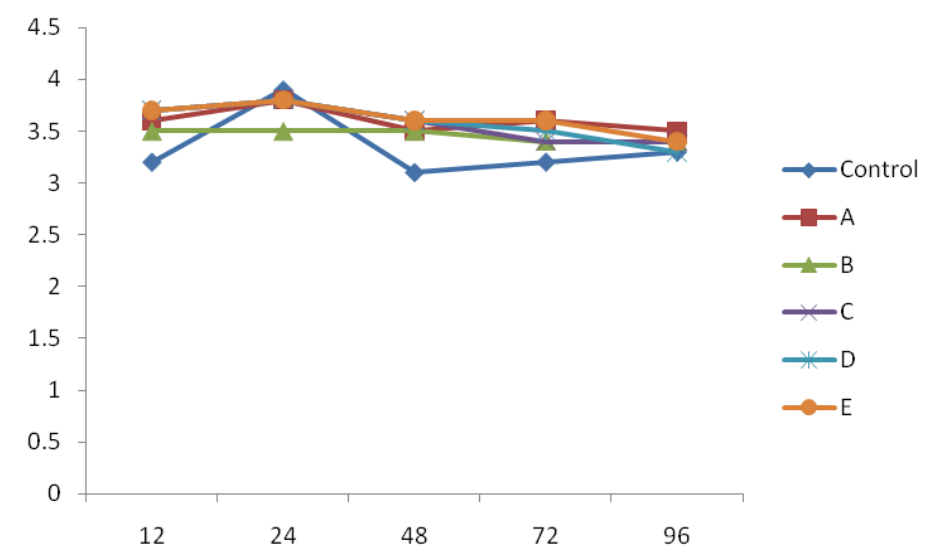

Figure 9. Monocytes (\%) of Sarotherodon melanotheron during the 96-h period.

which corresponds with studies on Tilapia guineensis and eels (Kirsch and Mayer, 1973; Hwang et al., 1989). Moreover, there was a significant reduction in the red blood cell and haemoglobin of the fish species. This reduction 
similar to that recorded on juvenile cobia (Rachycentron canadium) exposed to various degrees of salinity (Denson et al., 2003). The result of this study also corroborates the report of Munkittrick and Leatherland (1983) who stated that a change in water quality characteristic specific to an area inhabited by a fish population could affect their haematological indices. The changes in these parameters may be attributed to osmoregulatory dysfunction induced by changes in the total hardness, total alkalinity and salinity of the water body (Weirich and Tomasso, 1991).

Putman and Freel (1978) stated that different rates of fish activity demand different levels of metabolic activity; such activity requires several physiological adjustments including adjustments in the haematological parameters. The reduction in the $\mathrm{RBC}$ and $\mathrm{Hb}$ may be due to the presence of stressors which manifest in form of a change in the environment resulting to haemagglutination due to impaired osmoregulation (Rottman et al., 1992) or erythropoiesis in the organs responsible for the production of RBC. Packed cell volume is a major haematological parameter that changes with fish activity and environ-mental stress. In the course of this study, the PCV value of the fish species was observed to reduce with increasing concentration of crude oil and exposure time of the fish species. This may be attributed to the changes in water balance, which could cause a decrease in blood volume and an increase in the white blood cells resulting in reduced PCV (Cameron, 1970). On the other hand, the white blood cells of the fish species were observed to increase considerably with increase in experimental time. This increase was also observed in the highest crude oil concentration. The result agrees with the finding of Davids et al. (2002) who reported increase in size and monocytes of Tilapia guineensis and $S$. melanotheron after exposure to industrial effluents. The increase in WBC may be due to recruitment of more cells to combat the stressor (Ajani et al., 2007). This increase may also be attributed to non specific immune response to stress as a result of interaction of prolactin and cortisol hormones to restore ion balance in isosmotic salinity (Anyanwu et al., 2007), and a stimulation of the immune system in response to toxicity of crude oil.

The reduction observed in the leucocrit value may be due to the reaction of fish to the effect of the stress induced by the new environment. Dick and Dixon (1985) reported a significant reduction in leukocyte and lymphocyte of rainbow trout (Salmo gaidneri) after acute exposure to copper for $24 \mathrm{~h}$. This was attributed to a generalized stress response resulting from increased pituitary-interrenal activity. Alkahem (1994) also observed a decrease in total leucocrit of $O$. niloticus exposed to sub-lethal levels of nickel. This was attributed to a reduction in the number of circulating thrombocytes and lymphocytes due to a reduction in lymphocytes delivery to the circulatory system and a rapid destruction of cells which leads to an increased rate of peripheral removal of lymphocytes. Moroad and Houston (1988) attributed such lymphopenia to the lysis of lymphocytes after exposure to stressors in the environment. In our study, thrombocytes and lymphocytes of the fish species reduced in values during the experimental period. Thrombocytes were observed to drop sharply at $24 \mathrm{~h}$, while lymphocytes dropped gradually then sharply at $48 \mathrm{~h}$. This decrease may be attributed to lysis of the lymphocytes (lymphopenia) after exposure of the fish species to crude oil which altered the physicochemical characteristics of the water body. The decrease in thrombocytes and lymphocytes in crude oil exposed $S$. melanotheron is similar to that recorded in Atlantic $S$. gairdneri and $O$. niloticus by Matushima and Mariano (1996) who suggested a suppression of production from haematopoietic organs. The reduced lymphocytes and thrombocytes indicate a weakened defence and delay clotting in the event of an injury to the fish in the new environment.

Neutrophils and monocytes were observed to increase steadily during the experimental period and with increasing concentration, indicating a response of the two fish species to the crude oil concentrations particularly the two highest concentrations used. This increase is due to a non-specific immune response to stress, and the recruitment of more cells to combat the stressor (Ajani, et al., 2007). This study recommends further studies on haematological indices to ensure their appropriate use as index (biomarkers) in fish to monitor changes in environmental conditions, and organisms in healthy, disease and those undergoing stress conditions. This study recommends the integration of genetic toxicology and genetic ecotoxicology studies in Nigeria as being critical to the development of standardised biomonitoring programs.

\section{REFERENCES}

Ajani F, Olukunle OA, Agbede SA (2007). Hormonal and Hematological Responses of Clarias gariepinus (Burchell 1822) to Nitrite Toxicity. J. Fish. Int. 2:48-53.

Aldrin JF, Messager JL, Laurencin FB (1982). La Biochemie Clinique en Aquaculture. Interet et perspective cnexo. Actes Colloq. 14:291-326.

Alkahem HF, Ahmed Z, Al-Akel AS, Shamusi MJK (1994). Toxicity bioassay and changes in haematological parameters of oreochromis niloticus induced by trichloroform. Arab Gulf J. Sci. Res., 16: 581593.

Anderson DP (1974). Fish Immunology. Neptune TFH Publications, New Jersey. p 239.

Anyanwu PE, Gabriel UU, Anyanwu AO, Akinrotimi AO (2007). Effect of salinity changes on Haematological parameters of Sarotherodon melanotheron from Buguma Creek, Niger Delta. J. Anim. Veter. Adv. 6(5): 658-662.

Barham WT, Smit GL, Schonbec HJ (1980). The haematological assessment of bacteria infection in rainbow trout Salmon gairdneri (Richardson). J. Fish Biol. 17:275-281.

Bhaskar BR, Rao KS (1984). Influence of environmental variables on haematological ranges of milk fish, Chanos chanos (forskal), in brackish-water culture. Aquaculture 83:123-136.

Blaxhall PC, Daisley KW (1973). Routine haematological methods for use with fish blood. J. Fish Biol. 5:771-781. 
Brown BA (1980). Haematology, Principles and Procedure, 3rd Edition. Lea and Fabiger, Philadelphia. P 356.

Cameron JN (1970). The influence of environment variables on the hematology of pinfish, Lagodon Rhomboids and Stryred mullet Musil Cephalus Comp. Biochem. Physiol. 32:175-192.

Caruso G, Genovese L, Maricchiolo G, Modica A (2005). Haematological, biochemical and immunological parameters as stress indicators in Dicentrarchus labrax and Sparus aurata farmed in off-shore cages. Aquacult. Int. 13:67-73

Clarke S, White more DH, McMahon RF (1979). Consideration of Blood Parameters of Largemouth Bass, (Micropterus salmonides). J. Fish Biol. 14:147-154.

Dacie JV, Lewis SN (1991). Practical Haematology, Fifth edition. Churchhill Livingstone, Edinburgh. p.390.

Davids CBB, Ekweozor EAS, Daka ER, Dambo WB, Bartimacus EAS (2002). Effects of Industrial Effluents on some Hematological Parameters of Sarotherodon melenothero and Tilapia guineensis. Global J. Pure Appl. Sci. 8: 305-310.

Denson MR, Stuart KR, Smith TIJ (2003). Effects of salinity on growth, survival and selected Haematological parameters of Juvenile cobiRachycentron canadum. J. World. Aqucult. Soc. 34: 496-503.

Dick PT, Dixon DG (1985). Changes in Circulating Blood Levels of Rainbow Trout, Salmo gaindineri following acute and Chronic Exposure to Copper. J. Fish. Biol. 26:475-481.

Fedato RP, Simonato JD, Martinez CBR, Sofiaa SH (2010). Genetic damage in the bivalve mollusk Corbicula fluminea induced by the water-soluble fraction of gasoline. Mutat. Res. 700:80-85.

Hwang PP, Sun CM, Wus M (1989). Changes of plasma osmolality, Chloride concentration and gill Na-K-ATPase activity in tilapia Oreochromis mossambicus during sea-water acclimation. Mar. Biol. 100:295-299.

Kirsch R, Mayer GN (1973). Kinetics of Water and Chloride exchanges during adaptation of the European eel to sea water. J. Fish Biol. 27:259-263

Matushima ER, Mariano M (1996). Kinetics of the inflammatory reaction induced by genin in the Swim Bladder of Oreochromis niloticus (Ivile Tilapia) Braz. J. Vet. Res. Anim. Sci. 33:5-10.

Mirale JB (1982). Laboratory Medicine haematology, (6th Edn.). CV Mosby Co., London. p 883.
Moroad A, Houston AH (1988). Leucocytes and Leucopoiesis Capacity in Gold Fish, Cerassius averatus exposed to sub-lather levels of Cadmium. Aquacult. Toxicol. 13:141-154.

Munkittrick KR, Leatherland JF (1983). Haematocrit values in the feral goldfish, Crassus curatus as indicators of the health of the population. J. Fish Biol. 23:153-161.

Putman W, Freel RW (1978). Hematological Parameters of five Species of Marine Fishes. Comp. Biochem. Physiol. 61:585-588.

Rottman RW Francis-Floyd R, Durborow H (1992). The role of stress in fish disease. Southern Regional Aquaculture Centre (SRAC) Publication. p 474.

Schuett DA, Lehmann J, Guerlich R, Hamers R (1997). Haematology of Swordtail xiphiphorus helleri. I: Blood parameters and light microscopy of blood cells. J. Appl. Icthiyol. 13:83-89.

Siddiqui AK, Naseen S (1979). Blood Dyscrasia in a teloest Colisa fasciatus after acute exposure to sublethal concentrations of head. J. Fish Biol. 14:199-204.

Silveira R, Rigores C (1989). Caracteristics hemalogicas normales de Oreochronis aureus em cultivo. Rev. Latinoam Acuic. 39: 54-56.

Van V, Hattingh J (1978). The Effects of Toxicants on the Hematology of Labeo umbratus (Teleostei: Cyprindae). Com. Biochem. Physiol. C 83:155-159.

Wedemeyer GA, Gould RW, Yasutake WT (1983). Some haematological potentials and assessment methods. J. Fish Biol. 23:711-716.

Weirich CR, Tomasso JR (1991) Confinement- and transport-induced stress on red drum juveniles: effects of salinity. Progres. Fish Culturist 53:146-149.

Yaji AJ, Auta J (2007). Sub-lethal effects of monocrotophos on some haematological indices of African catfish Clarias gariepinus (Teugels). J. Fish. Int. 2(1):115-117. 